\title{
Mesoherbivory: the ascoglossan sea slug Placida dendritica may contribute to the restricted distribution of its algal host
}

\author{
Cynthia D. Trowbridge* \\ Department of Zoology, Oregon State University, Corvallis, Oregon 97331 \\ and Hatfield Marine Science Center, Newport, Oregon 97365, USA
}

\begin{abstract}
The influence of small herbivores in marine rocky intertidal communities has been largely ignored. From 1985 to 1990, I investigated the association of the oligophagous ascoglossan (=sacoglossan) sea slug Placida dendritica (Gastropoda: Opisthobranchia) with one of its algal food species, the crustose green alga Codium setchellii, along the central coast of Oregon, USA. The alga has a restricted local distribution: shaded rocky surfaces in low intertidal areas strongly influenced by sand scour and burial. During spring and summer, $P$. dendritica occurred on 6 to $32 \%$ of $C$. setchellii thalli at 3 low intertidal sites; mean densities were 7 to 12 sea slugs per occupied thallus. The sea slug composed a major, often numerically dominant, component of the herbivore fauna on the alga in spring and summer whereas the small snail Lacuna marmorata numerically dominated in fall and winter. Sea slugs damaged the alga more frequently and consumed it more rapidly than did co-occurring, generalist herbivores (e.g. snails, gammarid amphipods, idoteid isopods). The alga had a small-size refuge from the sea slug but not a low-density refuge: recruiting larvae were extremely effective at locating all transplants, even at low densities. Sea slugs often attacked damaged algal hosts more frequently than undamaged hosts. Because $C$. setchellii was more tolerant of physical disturbance than was $P$. dendritica, the alga had partial refuges from sea slugs in areas with high sand or wave disturbance. Under conditions of low sand movement and low wave force, sea slug herbivory may exclude the alga from low intertidal, rocky sites along the Oregon coast. The restricted distribution of C. setchellii, therefore, may reflect spatial variation in effects of disturbance on sea slug recruitment and herbivory.
\end{abstract}

\section{INTRODUCTION}

Plants are attacked by a diverse array of herbivores varying in size, mobility, and feeding habits. In terrestrial communities, the ecological roles of different types of herbivores (e.g. large grazing mammals and small phytophagous insects) have been extensively studied. Complementary information, however, for marine communities is sparse. Although numerous studies (Lubchenco \& Gaines 1981, Hawkins \& Hartnoll 1983. references therein) have focused on the ecological role of the larger, more obvious marine herbivores (e.g. fishes, urchins, large gastropods), comparatively little information is known about the trophic effects of smaller consumers - the mesoherbivores (Brawley \& Fei 1987, Hay et al. 1987). Although some workers use a specific size range to define mesoherbivores (e.g. 0.5

- Present address: Leigh Marine Laboratory, University of Auckland, Private Bag, Auckland, New Zealand to $2.0 \mathrm{~mm}$; Brostoff 1988), generally accepted mesoherbivore taxa include amphipods, isopods, polychaetes, and small gastropods.

The role of mesograzers in structuring marine macroalgal communities is not well known. Some mesoherbivores enhance macroalgal establishment, survival, or growth by removing epiphytes or ephemeral algae (Brawley \& Adey 1981a, b, D'Antonio 1985, Duffy 1990). Other mesoherbivores visibly damage macroalgal food, locally reduce algal biomass, or both (Fralick et al. 1974, Clark 1975, Jensen 1975, Nicotri 1977 , Norton \& Benson 1983, Gunnill 1985, Johnson \& Mann 1986, Clark \& DeFreese 1987, Salemaa 1987, Tegner \& Dayton 1987, Coen 1988a, b, Duffy 1990, Duffy \& Hay 1991). Predation, however, may limit mesoherbivory (Young et al. 1976, Van Dolah 1978, Nelson 1979a, b, 1981, Zimmerman et al. 1979, Warwick et al. 1982) and shape herbivore preferences for algal food and habitat (Van Dolah 1978, Nicotri 1980. Hay et al. 1987, 1988a, b, 1989, 1990a, b). 
Theoretically, mesoherbivory should be important to marine plants under conditions in which mesoherbivores are abundant and macroherbivores are not (Salemaa 1987). These conditions may occur for temperate opisthobranch sea slug-seaweed associations where specialist slugs are often abundant on their hosts (Clark 1975, Clark \& DeFreese 1987) but generalist meso- and macroherbivores are not because of effective defenses of the algae, intense predation on the generalists, or other factors. Because many temperate species of specialist slugs have wide geographic distributions and moderately high densities (Clark \& DeFreese 1987, Trowbridge 1989), the question of whether opisthobranch mesoherbivores affect host plant populations merits further attention.

I examine herein whether one marine mesoherbivore, an oligophagous sea slug, has a strong effect on the distribution and abundance of its algal hosts. I explore the conditions under which the sea siug Placida dendritica A. \& H. (Opisthobranchia: Ascoglossa) was abundant and its herbivory was ecologically significant to its host plants. In particular, I suggest that the sea slugs may contribute to the restricted between-habitat distribution of one of their primary algal hosts, Codium setchellii Gardn. (Chlorophyta: Codiaceae), along the central coast of Oregon, USA.

\section{SEA SLUG AND ALGAL NATURAL HISTORY}

Placida dendritica is common in warm-temperate to boreal coastal waters throughout the world (Schmekel \& Portmann 1982). The species has planktotrophic larvae (Clark 1975) and benthic adults. Larval recruitment occurs throughout the spring and summer (Clark 1975 , Trowbridge 1992), and sea slugs grow to sexual maturity ( $\sim 1 \mathrm{mg}$ wet mass) in less than 1 mo after settlement (Trowbridge 1992). P. dendritica (henceforth called Placida) is cryptic on its algal hosts because it retains ingested algal chloroplasts in gut diverticula. The herbivore, however, does not derive photosynthetic benefit from the retained chloroplasts (McLean 1976, Santisi 1985, Clark et al. 1990), in contrast to many other ascoglossan species (Hinde \& Smith 1974, Trench 1975, Clark \& Busacca 1978).

Along the coast of Oregon, Placida feeds on 3 species: the low intertidal green algae Codium setchellii, $C$. fragile (Sur.) Har, and Bryopsis corticulans Setch. (Trowbridge 1989, 1991a, 1992). Individual sea slugs often specialize on one host species and have limited capacity to survive on other co-occurring host species (Jensen 1989, Trowbridge 1991a). Thus, Placida populations are functionally subdivided on different host species, and the slug's dynamics on one species may be largely independent of its dynamics on other local host species. I focus herein on the slug's trophic interactions with the low intertidal, crustose green alga C. setchellii.

The alga ranges from Sitka, Alaska to Punta Baja, Baja California (Silva 1951). Placida occurs with Codium setchellii (henceforth called Codium) throughout the alga's geographic range. The alga exhibits a restricted within-habitat and between-habitat distribution: it inhabits primarily shaded, vertical rock surfaces in low intertidal areas strongly influenced by sand scour and burial (Silva 1951). Within this specific type of habitat, Codium is common but not abundant. Thus, the alga may be considered a 'predictably' scarce species (sensu Rabinowitz 1981) because of its wide geographic distribution, narrow habitat specificity, and low to moderate local abundance.

\section{METHODS}

Fieid surveys. Between-habitat distribution of Codium: In May and June 1987, I surveyed the density of Codium at 16 state parks, waysides, and access points along the central coast of Oregon $\left(44^{\circ}-45^{\circ} \mathrm{N}\right.$, $124^{\circ} 03^{\prime}-06^{\prime} \mathrm{W}$ ). These sites represented all accessible areas, along $\sim 113 \mathrm{~km}$ of coastline, that had rocky substrate in the low intertidal zone (between $+0.4 \mathrm{~m}$ and $-0.8 \mathrm{~m}$ ). The nature of the rocky substrate (e.g. boulder field, urchin bed, flat bench) and the presence of any sand overlying the rock were noted. Depending on the nature and availability of the rocky substrate, I surveyed 2 to 3 band transects $(1 \mathrm{~m} \times 20-25 \mathrm{~m})$ running parallel to the shore at each site and counted established Codium thalli ( $>1 \mathrm{~cm}$ in diameter) in each transect. I did not include algal germlings $(1 \mathrm{~mm}$ to $1 \mathrm{~cm}$ ) because the spatial and temporal patchiness of Codium recruitment would bias the data. I also measured each crustose thallus (2 diameters perpendicular to one another). Because the thalli occurred at low densities, I calculated percent cover of Codium directly (surface area of the alga divided by intertidal area sampled) rather than using the random dot method. To make the calculation, I assumed that each crustose thallus was circular. This assumption was reasonable for the algal size range I examined $(0.2$ to $18.3 \mathrm{~cm})$.

Codium size-specific morphology: Although Codium is a crustose alga, its surface varies widely in 3 dimensional relief. To quantify size-specific morphological differences, in June 1985 I measured 61 thalli (2 diameters perpendicular to one another per thallus) and then categorized the extent of surface rugosity on a scale from 1 (smooth surface) to 3 (highly rugose). I also noted the presence or absence of any upright portions. To examine how Codium mass varied with thallus size, I destructively sampled 47 thalli in March 1985 from Seal Rock South. In the laboratory, I measured (as above) and weighed each thallus ( $g$ wet mass). 
Herbivore abundance \& grazing damage: From April 1985 to September 1987, I monitored the herbivores on Codium at five sites along the central coast of Oregon $\left(44^{\circ} 16^{\prime}-41^{\prime} \mathrm{N}, 124^{\circ} 05^{\prime}-06^{\prime} \mathrm{W}\right)$. From north to south, these sites were Yaquina Head North, Seal Rock North and South, and Strawberry Hill North and South. I selected 2 areas at Seal Rock and Strawberry Hill because of their markedly different patterns of sand dynamics (D'Antonio 1986). The low intertidal zone was frequently, though unpredictably, buried by sand ( $\mathrm{cm}$ to $\mathrm{m}$ in depth). I ranked the relative degree of sand burial of known Codium thalli at each site as: (0) most to all thalli exposed, (1) thalli partially buried by sand, and (2) thalli totally buried. The number of thalli exposed and hence, sampled, were often constrained by high sand levels. For example, the thalli censused at Strawberry Hill North were buried by over a meter of sand for at least 14 mo continuously during this study. When the sand moved off the shore, many of the marked thalli were still alive.

From April 1985 to March 1987, I surveyed known Codium thalli monthly at each site, noting the abundance of generalist and specialist herbivores. For clarity, I summarized the data herein as the mesoherbivores associated with the alga during four 6 mo periods: April to September 1985, October 1985 to March 1986, April to September 1986, and October 1986 to March 1987. These intervals reflect periods in which the sea slug was present versus absent on its hosts (Trowbridge 1992). Because Placida was patchily distributed (Trowbridge 1991b), I supplemented the data above with observations of slug abundance on additional thalli during most months when tidal conditions permitted.

During herbivore censuses, I noted the extent of any grazing damage. Damage was ranked based on percentage of algal thallus area affected: (0) no damage, (1) $<25 \%$ thallus area damaged, (2) $25-75 \%$ area damaged, and (3) $>75 \%$ area damaged. Placida feeding was distinctive because the sea slugs sucked the chloroplast-rich algal protoplasm from the algal cortex; grazed tissue was pale green and mushy compared to the dark green, firm appearance of ungrazed tissue. Snails, limpets, and chitons abraded the edges and occasionally the surface of Codium thalli whereas amphipods and isopods shredded the thalli and separated utricles. I conducted a laboratory experiment (described below) to check whether the observed damage was produced by the associated herbivores. Finally, recently 'unburied' Codium thalli exhibited no signs of physical abrasion but were extremely mushy and olive green (due to degradation of chlorophyll).

Laboratory feeding experiment. General procedure: To quantify the grazing damage and feeding rates of different low intertidal mesoherbivores on Codium, I conducted a feeding experiment at the Hat- field Marine Science Center in Newport, Oregon in August 1990 when Placida was on its algal hosts. I collected circular plugs of Codium $1.6 \mathrm{~cm}$ diameter, $\sim 0.9 \mathrm{~g}$ wet mass) and kept them in running seawater for $2 \mathrm{~d}$ prior to use. At the beginning and end of the experiment, I weighed Codium plugs to the nearest $0.01 \mathrm{mg}$. Because of the standardized size of the pieces, initial masses were quite uniform. I placed herbivores in 0.51 containers with fresh seawater and Codium tissue and placed the experimental containers in a shallow, running-seawater table.

Grazing damage: I visually estimated the grazing damage to the Codium tissue by noting algal texture on a relative scale from firm (0) to mushy (3) and by visually categorizing the extent of thallus surface damaged. Because of the extremely obvious differences, I considered more quantitative estimates unnecessary. I compared algal texture, surface damage, and edge damage values, using non-parametric Kruskal-Wallis tests and the non-parametric analog of Student-Newman-Keuls test ( $\operatorname{Zar} 1984$ ). For texture values, I also calculated a Spearman correlation coefficient for the relation between my visual estimate of slug grazing damage and actual mass loss.

Feeding rates: To quantity feeding rates of mesoherbivores, in August 1990 I conducted a 2-way factorial experiment with herbivore taxon and algal species as fixed factors. Mesoherbivore treatments were: the snail Lacuna marmorata (10 container $\left.{ }^{-1}\right)$, gammarid amphipods (20 container $\left.{ }^{-1}\right)$, the isopod Idotea wosnesenskii ( 1 container $^{-1}$ ), the slug Placida dendritica (20 container $^{-1}$ ), and a no-herbivore control. Crustacean herbivore abundances were higher than observed field values on Codium: amphipods and isopods were rarely seen on the alga in the field (see 'Results'). In contrast, snail and slug numbers were within the range of natural densities. For example, on Codium on the shore, Placida formed feeding groups ranging up to 70 to 90 sea slugs on small regions on the thalli (Trowbridge $1991 \mathrm{~b}$ ). In the experiment, I used 20 slugs per container because some individuals in the laboratory move off the host to mate and deposit egg masses.

Algal choice treatments were $\sim 0.9 \mathrm{~g}$ amounts of Codium offered (1) alone ('no-choice') and (2) along with 2 co-occurring algal species ('choice'): the common green alga Ulva lactuca $(\sim 0.3 \mathrm{~g})$ and the red alga Neorhodomela larix $(\sim 1.2 \mathrm{~g})$. Choice treatments simulated field conditions more closely than no-choice treatments. I used 5 replicates for each of the 10 treatments. I weighed Codium at the beginning and end of the $6 \mathrm{~d}$ experiment and herbivore masses at the end. Using these data, I made 3 separate statistical analyses.

First, to test whether the 8 experimental treatments differed from the 2 no-herbivore controls, I calculated the percent daily algal mass loss of each treatment as 
(initial mass - final mass) $\times 100 /($ initial mass $\times$ days $)$. Because this calculation was sensitive to initial differences, I checked that initial mass values were statistically indistinguishable. My use of standardized plugs of Codium tissue ensured that this assumption was met. I also checked that the data were normally distributed and the variances were homogeneous, using Lilliefors test and Bartlett's test (Wilkinson 1988). I then analyzed the percent daily mass loss data with a 2-way analysis of variance (ANOVA).

After establishing that some mesoherbivores reduced algal mass, I made 2 comparisons among the 8 experimental treatments: $\mathrm{mg}$ algal mass loss (1) per $\mathrm{g}$ herbivore and (2) per individual per day. Because I had already established a significant herbivore effect, I refer to these 2 mass loss values as herbivore consumption rates. Because these data were not normally distributed, I used non-parametric analogs of 2-way ANOVAs (extension of Kruskal-Wallis test) (Zar 1984).

Algal transplant experiments. General procedures: In 1988 and 1989, I experimentally tested the effect of algal density, grazing damage, and wave exposure on Placida recruitment. I selected ine iransplani site, Boiler Bay State Park, (1) because Codium setchellii occurred at extremely low densities, rendering movement of adult sea slugs from established thalli to the transplants unlikely and (2) because summer sand scour and sand burial were negligible (D'Antonio 1986). Although the sea slugs theoretically may move from established $C$. fragile or Bryopsis to transplanted C. setchellii, individual Placida have limited capacity to switch host species (Trowbridge 1991a). Slug recruitment to Codium transplants, therefore, should have been primarily from settlement of planktonic larvae.

I placed 25 to $30 \mathrm{~g}$ of defaunated Codium, collected from Seal Rock South, in individual plastic mesh bags $\left(25 \mathrm{~cm} \times 10 \mathrm{~cm}\right.$ bags $_{i}$ mesh opening 6 to $8 \mathrm{~mm}$; (Protex, Norplex Inc., Kent, WA, USA), and attached the bags with monofilament line to stainless steel screws cemented in the rocky substrate. Sample sizes ranged from 5 to 9 replicates per treatment group in the various experiments. Transplants were distributed at randomly selected points, at least $2 \mathrm{~m}$ apart, along a $20 \mathrm{~m}$ transect line placed horizontally along the shore. The location of the experiments in the lower end of the low intertidal zone at Boiler Bay ( $\mathrm{ca}-0.5$ to $-0.8 \mathrm{~m}$ ) and the timing of the experiments limited desiccation stress to the transplants. Usually after $4 \mathrm{wk}$, I collected, weighed, and preserved the algal samples and associated fauna in $70 \%$ ethanol. In one experiment, however, I collected the samples after 2 wk because of extremely high slug recruitment.

I selected this transplant technique for 3 reasons. First, as Codium matured, it became partially to totally detached from the substrate. Thus, my manual removal of thalli mimicked a natural process experienced by the alga. Second, as the alga detached from the substrate, the free edges curled under, causing the thick crust to buckle. Attaching entire thalli to new substrate with epoxy putty or other adhesive, therefore, was not possible. Third, Placida exhibited no preference between undamaged and physically damaged Codium tissue though the herbivore did prefer host tissue damaged by feeding conspecifics (Trowbridge 1991b).

Algal density experiment: To test whether Codium had a low-density refuge from Placida, I transplanted the alga in 2 spatial arrangements: 1 and 4 thalli per $0.25 \mathrm{~m}^{2}$ quadrat with 5 replicates per treatment. Patch size and algal density, therefore, covaried. The effective densities of these treatments depended on the spatial scale of observation. For example, I transplanted a total of 25 thalli along a $20 \mathrm{~m}^{2}$ band transect: the resulting density was 1.25 thalli $\mathrm{m}^{-2}$. Because of the scarcity of Codium at Boiler Bay, the effective thailus density was even lower if we examine the low intertidal zone at the site.

I conducted the transplant experiment twice, once under high recruitment conditions of Placida $(\sim 200$ sea

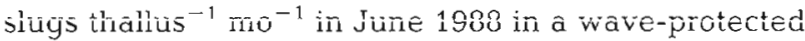
area) and once under low recruitment conditions $(\sim 30$ sea slugs thallus ${ }^{-1} \mathrm{mo}^{-1}$ in August 1988 in an waveexposed area). After checking the assumptions of homogeneity of variances and normality of data, I analyzed density results in the first experiment with a Student's $t$-test and results in the second experiment with a Mann-Whitney test.

Algal damage experiment: To test how Placida grazing damage on Codium influenced subsequent slug attack, I conducted 2 field experiments. To control the initial extent of damage, I placed $25 \mathrm{~g}$ amounts of Codium in 0.51 containers with seawater in a running seawater table in the laboratory and added 50 sea slugs to each experimental thallus and none to control thalli. Sample sizes ranged from 7 to 9 replicates per treatment group in the 2 experiments. After a 2 wk period, Codium exposed to slug feeding became extensively damaged; control thalli were not damaged. I then removed the sea slugs and transplanted the thalli to Boiler Bay. I conducted this experiment twice: once under conditions of low Placida recruitment $(\sim 10$ sea slugs thallus ${ }^{-1} \mathrm{mo}^{-1}$ in August 1988 at an exposed locality; $\mathrm{n}=7$ ) and once under conditions of high recruitment $\left(\sim 100\right.$ sea slugs thallus ${ }^{-1} \mathrm{mo}^{-1}$ in June 1989 at a protected locality, $\mathrm{n}=9$ ). I compared mean slug densities, using Student's $t$-tests. I checked the assumptions of homogeneity of variances and normality as previously described.

Wave exposure experiments: To test whether Codium had a partial refuge from Placida at high wave force, in June 1988 I transplanted defaunated, preweighed Codium to 8 low intertidal locations of varying 
wave exposure at Boiler Bay: 3 wave-protected areas, 2 moderately exposed areas, and 3 highly exposed areas. At each location, I attached 5 replicate samples at randomly selected points along a $20 \mathrm{~m}$ transect placed horizontally along the shore. After $4 \mathrm{wk}$, I collected the samples, counted the sea slugs, and compared mean slug densities, using a nested analysis of variance (sites nested within wave exposure level) with log-transformed data. I tested the hypothesis that slug abundance varied significantly with wave exposure. I also calculated mass loss of algae in the different areas and compared values of mass loss per sea slug on the algae to values of sea slug grazing from the laboratory experiment. Similarity in the values may indicate that Placida herbivory created the observed algal mass loss

To evaluate whether sea slug herbivory may result in significant tissue loss to Codium over a longer period of time, in May 1989 I transplanted thalli to areas characterized by high and low Placida recruitment: namely 3 wave-protected and 3 moderately wave-exposed areas at Boiler Bay. I transplanted 3 to 4 defaunated, preweighed thalli at each of the 6 localities. After 7 wk, I collected the samples, weighed the remaining algae checked the normality of data and homogeneity of variances, and then compared the mean Codium mass loss using a nested analysis of variance. I tested the hypothesis that algal mass loss varied significantly with wave exposure. My visual inspection of algal samples at the beginning, middle, and end of the experiment indicated extensive grazing damage, particularly at the protected localities. The damage was clearly attributable to sea slug grazing (see 'Laboratory feeding experiment').

A potentially confounding factor of the transplant experiments was spatial variation in algal growth. Because of the small size and high recruitment of Placida (Trowbridge 1989, 1992), I could not exclude sea slugs from Codium as a no-herbivore control to measure algal growth without creating a confounding mesh effect. Three types of evidence, however, suggest that differential mass loss was probably not problematic. First, based on my field measurements (author's unpubl. data), Codium was a slow-growing perennial alga, particularly during the summer, so differential growth or regression cannot account for biomass losses of 50 to $100 \%$ of a thallus during the $7 \mathrm{wk}$ experiment. Second, in the winter of 1986, I transplanted Codium in window-screening that excluded all mesoherbivores. The alga survived well at the protected areas of Boiler Bay for $\sim 4$ to 5 mo (at which point the mesh rotted and the samples were lost). Thus, the alga can survive in non-sandy, wave-protected areas, but some unidentified ecological factor restricted the alga. Third, when Codium occurred at non-sandy sites, it typically lived in wave-swept habitats, particularly boulder fields that were exposed to high, turbulent flow.

\section{RESULTS}

\section{Restricted algal distribution}

Codium setchellii was patchily distributed on rocky substrata in the low intertidal zone. Natural densities ranged from 0 to 10 established thalli ( $>1 \mathrm{~cm}$ diameter) $\mathrm{m}^{-2}$. Mean Codium abundance (Fig. 1A, B) was 3.3 thalli $\mathrm{m}^{-2}$ and $1.8 \%$ primary cover on sand-scoured, low intertidal benches. The alga was 10 fold less abundant at non-sandy, boulder fields and was not observed in other types of habitats during the survey. Codium was significantly more abundant on sandy benches than in non-sandy boulder fields (Mann-Whitney, $U=$ 81.0, $\mathrm{p}=0.003$ for density; $U=33.5, \mathrm{p}=0.009$ for percent cover). The few Codium thalli found at nonsandy sites were similar in size to those at sand-influenced sites ( $G$-test, $G=1.41$, df $=4, p>0.75$; Fig. 1C) but appeared to grow lower in the intertidal zone.

\section{Sea slugs dominated mesoherbivore fauna}

Placida dendritica was the numerically dominant herbivore associated with Codium in spring and summer whereas the generalist snail Lacuna marmorata was numerically dominant in fall and winter (Fig. 2A). Limpets and chitons composed $<15 \%$ of the associated fauna whereas gammarid amphipods and idoteid isopods were never common $(<1 \%$ of the fauna) despite the inclusion of nocturnal and diurnal observations. Although the composition of associated mesoherbivores varied among sites and between years (Fig. 2B, C), the sea slugs were typically a major part of the spring and summer fauna. In 1986, I found few herbivores on Codium censused at Yaquina Head North. Even though no sea slugs were found on the thalli monitored for all herbivores, slugs were present on the supplemental thalli that I censused solely for Placida.

Because many mesoherbivores, particularly amphipods and isopods, are highly mobile, my observations during low tide may have underestimated the density of some taxa. To evaluate this problem, I noted herbivore densities on submerged Codium in the feeding damage and consumption rate experiment discussed below. When co-occurring algae (Ulva lactuca, Neorhodomela larix) were present, few generalist herbivores were on Codium.

\section{Sea slug herbivory damaged alga}

Placida damaged Codium more frequently and severely than did other mesoherbivores. In the field, sea slugs were associated with grazing damage significantly 


\section{A. CODIUM DENSITY}

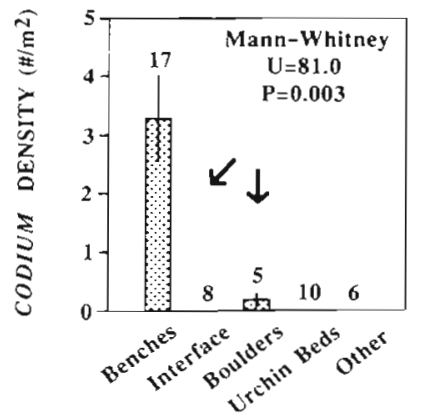

B. CODIUM COVER

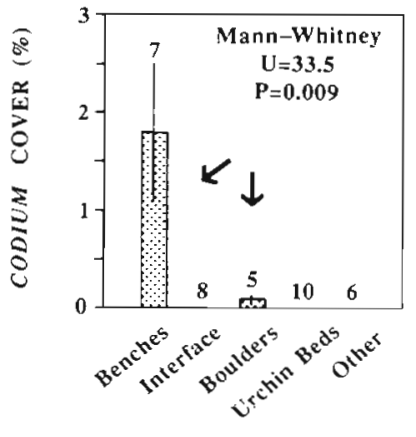

C. CODIUM SIZE

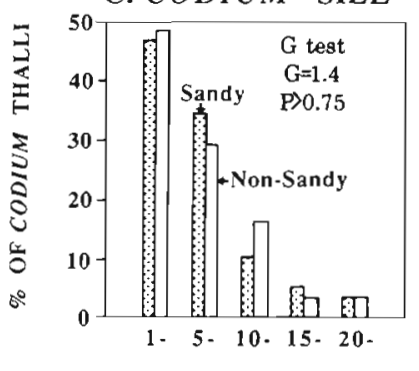

THALLUS DIAMETER $(\mathrm{cm})$

Fig. 1. Codium setchellii. Density (A), percent cover (B), and thallus size (C) in 46 low intertidal, band transects (20 to $25 \mathrm{~m}^{2}$ ) at 16 sites along the central coast of Oregon, USA Quantitative data were collected in May and June 1987 Qualitative surveys were made in other years to confirm the documented distribution pattern. Numbers above each bar: total no. of transects in each sample; rocky benches: extensive rocky platforms; interface: rocky surfaces juxtaposed with sandy beaches; boulder habitats: boulder fields on rocky benches; urchins beds: rocky substrate dominated by sedentary purple urchins. Mann-Whitney tests (A, B) compare values of algal abundance for rocky bench and boulder-field habitats. $G$-test in (C) compares algal size-frequency at sandy and non-sandy sites

more frequently than the generalist herbivores ( $G$-test, $G$ $=48.4 \mathrm{df}=1, \mathrm{p}<0.001$, Table 1 ), and slug density was positively correlated with my visual estimates of grazing damage (Pearson correlation, $\mathrm{r}=0.604, \mathrm{n}=611$ thalli, $p<0.001$ ). These field observations, however, underestimated the extent of sea slug grazing damage for 2 reasons. First, I quantified the frequency that Placida was associated with grazing damage, not the frequency with

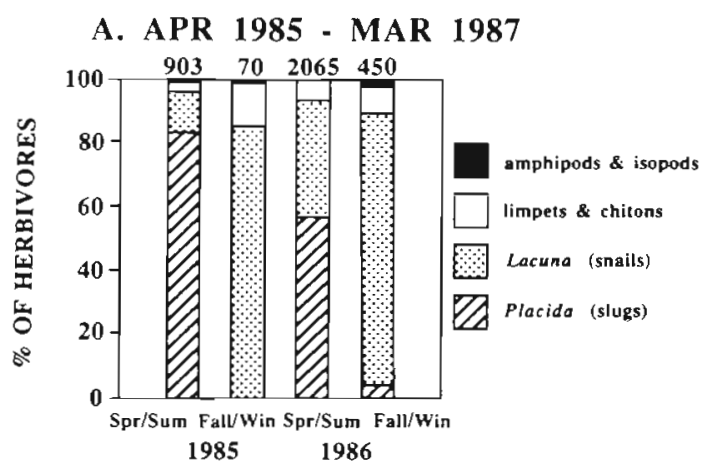

B. APR - SEP 1985

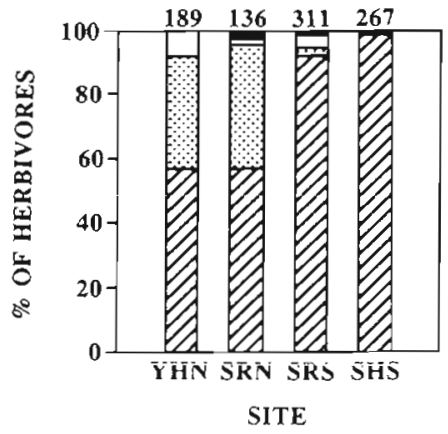

C. APR - SEP 1986

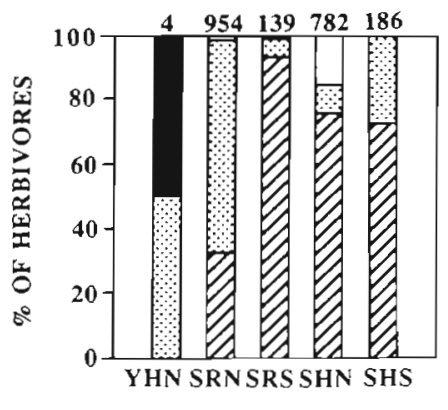

SITE

Fig. 2. (A) Mesoherbivores associated with Codium setchellii from April 1985 to March 1987 at 5 sites along the Oregon coast; data combined for all sites and summarized in four 6 mo periods for clarity; sample sizes ranged from 25 to 48 thalli with herbivores during the fall/winter periods and 192 to 252 during the spring/summer periods; numbers above each bar: total no. of herbivores quantified per sample. (B, C) Betweensite and between-year variation in mesoherbivore composition during the spring and summer Site names abbreviated. Strawberry Hill North (SHN) not included in (B) because it was buried by sand the entire 6 mo period

which Codium exhibited grazing damage. Second, I observed that damaged thalli often fragmented or disappeared between monthly surveys.

In the laboratory, Placida was the only mesoherbivore examined that significantly affected algal texture or damaged thallus surface of Codium (Fig. 3A, B). Fur- 


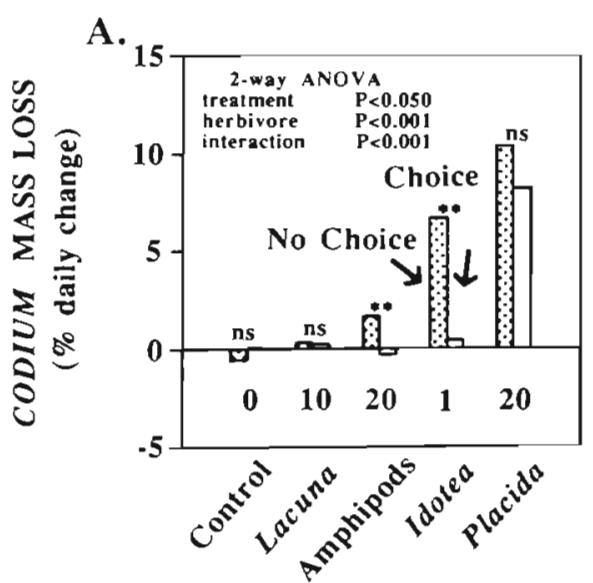

B.

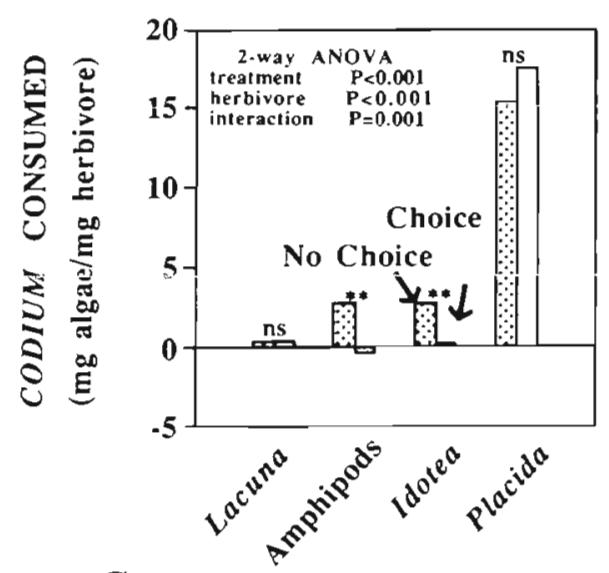

C.

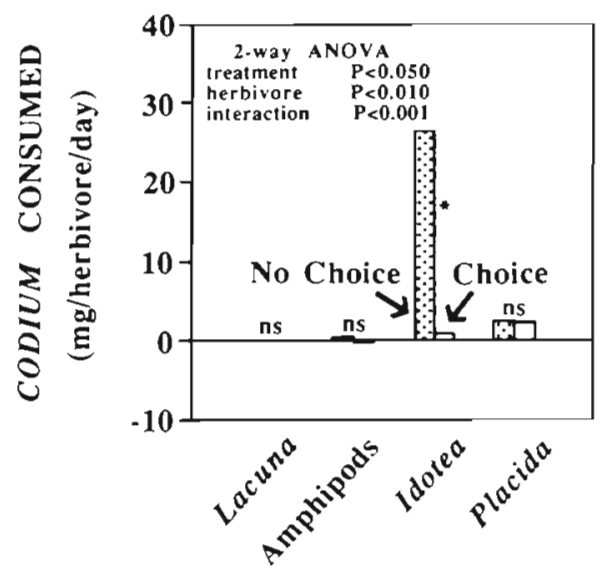

Fig. 4. Codium setchellii. Mass loss to different low intertidal mesoherbivores when offered alone ('no-choice') or with small amounts $(0.3$ to $1.2 \mathrm{~g})$ of Ulva lactuca and Neorhodomela larix ('choice'). Replication was 5 samples per treatment Data expressed as (A) percent daily mass loss, (B) algal mass consumed per mass of herbivore, (C) algal mass consumed per herbivore per day. Numbers below each bar in (A): no. of herbivores per replicate container. Control treatments were necessarily excluded from $(B)$ and $(C)$. ${ }^{\cdot}$ and $\cdots$. values differed significantly $(p<0.05$ and $p<0.01$ respectively) between choice and no-choice treatments for a given herbivore taxon; $n s$ : means did not differ significantly $(p>0.05)$
Table 2. Codium setchellii. Size-specific differences in percentage of thalli attacked by Placida dendritica. n: no. of thalli examined

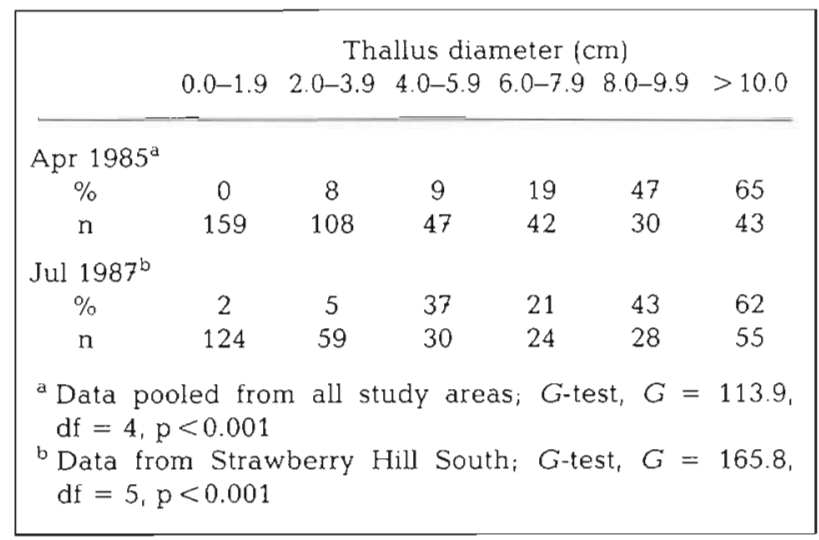

A. SURFACE RUGOSITY

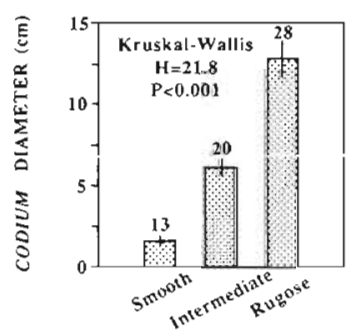

SURFACE RUGOSITY

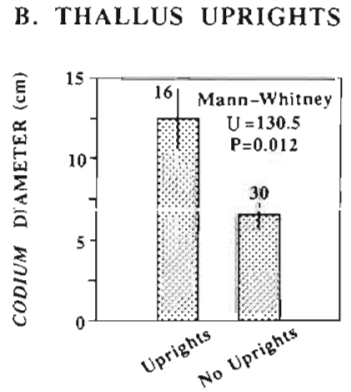

THALLUS MORPHOLOGY
Fig. 5. Codium setchellii. Size-specific differences in thallus morphology. Data collected from 61 thalli at Seal Rock North and Strawberry Hill South in July 1984. Numbers above each bar: no. of thalli examined

of Placida groups occurred in the depressions of the thallus surface (author's pers. obs.), larger thalli appear to have more area suitable for sea slugs than do small thalli.

\section{No low-density refuge}

Small-scale differences in Codium density and patch size did not affect sea slug recruitment. Placida abundance did not differ significantly between the 2 treatments under conditions of high (Student's $t$-test, $t=$ $0.20, p=0.842$ ) or low larval recruitment (Mann-Whitney test, $U=23.5, \mathrm{p}=0.345$ ). Codium, therefore, did not have an effective refuge in rarity from Placida, even at low sea slug densities: the recruiting herbivores were extremely effective at locating all the algal transplants.

\section{Damaged algal thalli often reattacked}

The effect of sea slug grazing damage on subsequent slug attack of algal hosts varied. Under conditions of high 


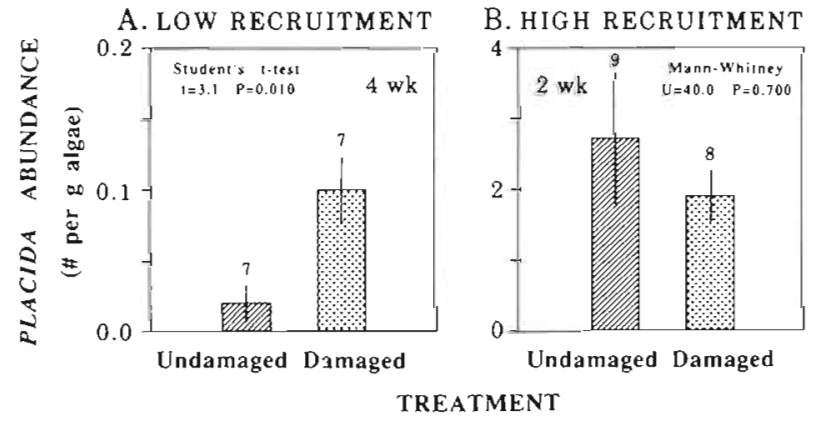

Fig. 6. Placida dendritica. Mean abundance ( $\pm 1 \mathrm{SE}$ ) of recruits on Codium setchellii thalli experimentally damaged or undamaged by feeding activities of conspecifics. The low sea slug recruitment experiment (A) was conducted for $4 \mathrm{wk}$ in August 1988 at a wave-exposed area of Boiler Bay; the high recruitment experiment (B) was conducted for $2 \mathrm{wk}$ in June 1989 at a protected area. Sample sizes indicated above each bar

wave action and low slug recruitment, Placida abundance was significantly greater on Codium experimentally damaged by sea slugs than on undamaged control algae (Fig. 6A, Student's $t$-test, $t=3.1, p=0.010$ ). Damaged thalli were reattacked, resulting in extensive damage. In contrast, under conditions of low wave action and high larval recruitment, slug recruitment was similar on damaged and undamaged thalli (Fig. 6B, MannWhitney, $U=40.0, \mathrm{p}=0.700$ ). Both experiments suggest that Codium did not have inducible defenses effective against recruiting Placida. In fact, Placida growth rate was significantly greater on damaged than undamaged Codium thalli (Trowbridge 1991a, b).

\section{Physical disturbance}

Partial high-disturbance refuge

Two types of physical disturbance may provide Codium thalli with a partial refuge from sea slugs: (1) sand scour and burial, and (2) wave action or force. Because of unpredictability in the frequency and severity of sand disturbance along the central coast of Oregon (D'Antonio 1986, author's pers. obs.), field experiments evaluating the effect of sand on slug abundance were not feasible. Sea slug abundance (Table 3), therefore, was based on long-term monitoring of 3 sites that experienced different degrees of sand disturbance: one site that experienced frequent, severe sand inundations, one site with moderate disturbance, and one site with low sand movement. Both the percentage of Codium attacked by Placida and the mean number of sea slugs per occupied thallus tended to decrease with increased sand disturbance (Table 3), suggesting that Codium may have a partial refuge from slug herbivory in areas of high sand movement.

Codium may also have a partial refuge from Placida in areas of high wave force (Table 4). Although sea slugs recruited to all the transplants, slug abundance per thallus decreased significantly with increased wave exposure (nested ANOVA, $F=11.0, p<0.001$ ). In addition, final Codium mass decreased significantly with decreased wave exposure (nested ANOVA, $F=$ $3.6, \mathrm{p}=0.011$ ), and algal loss was positively correlated to Placida density (Spearman correlation, $\mathrm{r}_{\mathrm{s}}=0.335$, $\mathrm{n}=40$ thalli, $\mathrm{p}<0.05$, data pooled from 8 transplant localities). When I divided the algal mass loss values by the number of slugs per thallus and days of the experiment, the resulting rates (Table 4) ranged from 1 to $6 \mathrm{mg}$ (wet mass) slug ${ }^{-1} \mathrm{~d}^{-1}$. Because these calculated rates were similar to the laboratory-derived slug consumption rates ( 2 to $5 \mathrm{mg} \mathrm{slug}^{-1} \mathrm{~d}^{-1}$ ), Placida herbivory may account for most, if not all, of the Codium mass loss. For 2 reasons, caution should be used in interpreting an apparent positive relation between feeding rate and wave exposure. First, field rates of algal mass loss may reflect actual herbivore consumption and/or mass loss resulting from herbivore grazing damage. Second,

Table 3. Placida dendritica abundance on Codium setchellii in situ in spring and summer 1985-86 at 3 sites characterized by differential frequency and severity of sand disturbance (Low, Moderate, High). Relative sand levels were estimated on scale of 0 (all thalli exposed) to 2 (all buried by sand). Values in brackets: no. of sampling dates for sand or no. of algal thalli examined, respectively. Strawberry Hill North was not included because it was completely buried by sand during 1985; Yaquina Head North was not included because it was influenced by sand scour rather than periodic sand inundations

\begin{tabular}{|c|c|c|c|c|}
\hline & $\begin{array}{l}\text { Low } \\
\text { Strawberry Hill South }\end{array}$ & $\begin{array}{c}\text { Moderate } \\
\text { Seal Rock South }\end{array}$ & $\begin{array}{c}\text { High } \\
\text { Seal Rock North }\end{array}$ & $\mathrm{p}$ \\
\hline $\bar{x}$ sand level & $0.08(12)$ & $0.33(12)$ & $0.72(18)$ & $0.005^{\mathrm{a}}$ \\
\hline$\%$ thalli attacked & $32 \%(1321)$ & $19 \%(770)$ & $6 \%(1161)$ & $<0.001^{\mathrm{b}}$ \\
\hline $\begin{array}{l}\bar{x} \text { no. Placida per } \\
\text { occupied thallus }\end{array}$ & $11.9(159)$ & $8.9(110)$ & $6.8 \quad(73)$ & 0.061 \\
\hline
\end{tabular}


Table 4. Placida dendritica abundance on Codium setchellii transplanted to 8 areas at Boiler Bay ( 3 wave-protected, 2 intermediate, and 3 exposed areas) for $4 \mathrm{wk}$ in July 1988. Values in brackets: no. of thalli

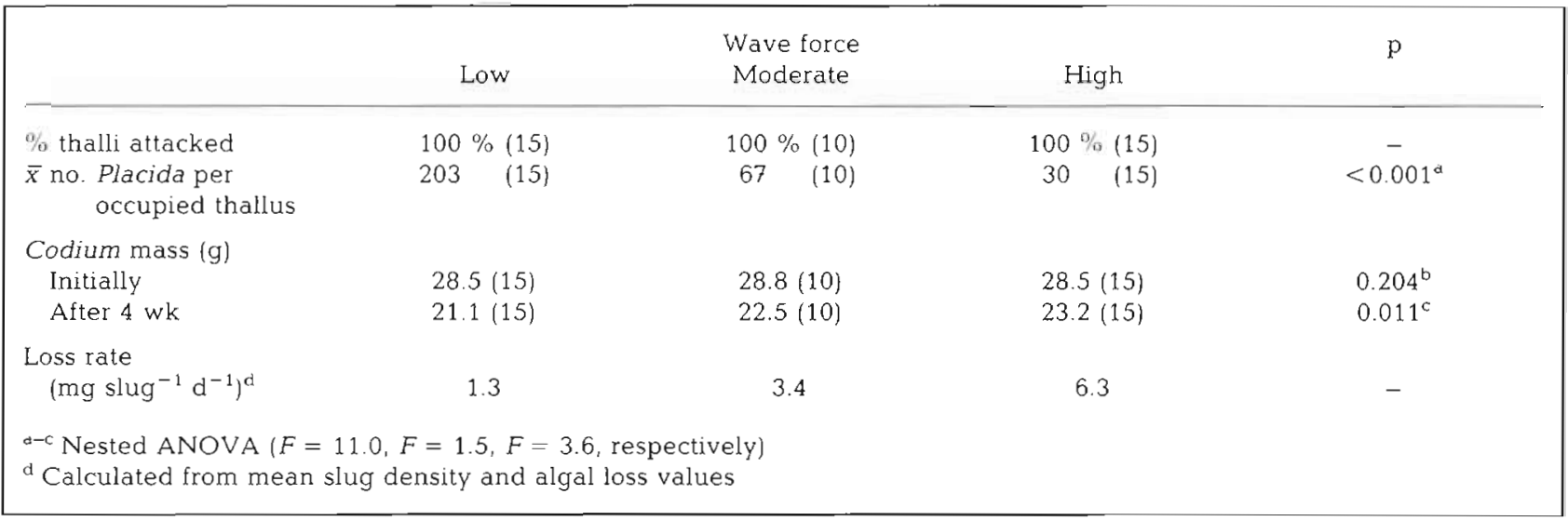

the absence of an error term for calculated values prevents a rigorous comparison.

\section{Figh digdi lissue loss ouisidie refuyes}

The spatial pattern of mass loss of Codium transplanted to Boiler Bay for 7 wk (Fig. 7) paralleled the gradient of slug abundance (Table 4) and, presumably, grazing intensity. The final mass of Codium varied significantly with wave exposure (nested ANOVA, $F=$ $4.0, \mathrm{p}=0.024)$. In 3 wave-protected areas, Codium transplants lost, on average, 40 to $80 \%$ of their mass in $7 \mathrm{wk}$; in 3 areas of intermediate wave exposure, transplants lost little mass. Although high-exposure areas were not used in this experiment because of limitations due to tidal conditions, extrapolation of these results to more exposed areas suggest that algal mass loss would probably be quite low.

Several lines of indirect evidence indicated that this pattern of algal mass loss was probably due to slug herbivory. First, the sea slugs composed over $90 \%$ of the herbivores on the transplants both in this experiment and the previous wave exposure experiment. Second, the slug was the only herbivore that produced appreciable grazing damage to Codium when offered the alga in the presence of the other algal species (Table 1, Fig. 2). Third, slug abundance was positively correlated to visual estimates of thallus damage on Codium thalli in situ (Pearson correlation, $\mathrm{r}=0.604$, $\mathrm{n}=611, \mathrm{p}<0.001)$, and visual estimates of damage were correlated to algal mass loss in the laboratory (Spearman correlation, $\mathrm{r}_{\mathrm{s}}=0.805, \mathrm{n}=10, \mathrm{p}=0.005$ ). Fourth, my observations of the algal samples at the middle and end of the experiment showed clear signs of Placida feeding and moderate to high densities of sea slugs.

\section{Sea slugs may restrict algai distribution}

An intriguing question is whether sea slug herbivory may reduce or eliminate Codium at low disturbance areas suchi as the noni-sandy, wave-protected areas of Boiler Bay. To evaluate the potential effect of slug herbivory, I used (1) field-derived estimates of Codium size, (2) laboratory estimates of slug feeding rates, and (3) field estimates of slug densities. I set $30 \mathrm{~g}$ of Codium ( $\sim 10 \mathrm{~cm}$ diameter thallus) as the maximum mass that would be lost because most thalli $(\sim 80 \%)$ at my study sites were smaller than that size (Fig. 1C). Based on my calculations (Fig. 8), naturally occurring densities of Placida had the potential to consume entire, slowgrowing, perennial Codium thalli during the 6 mo

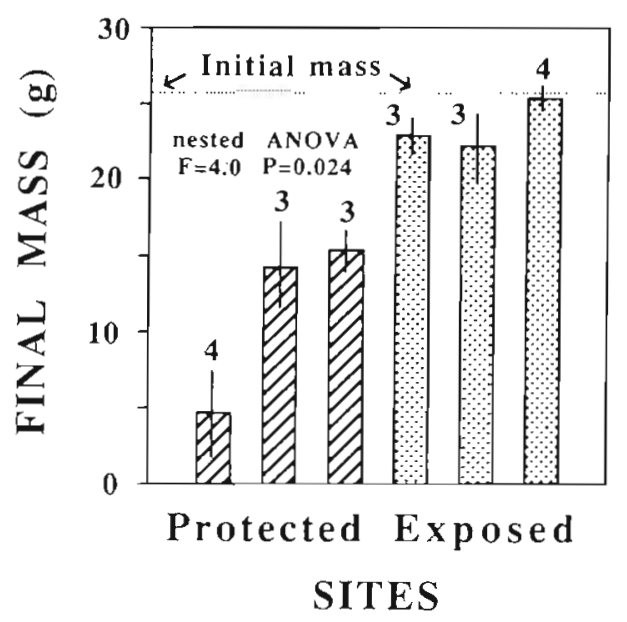

Fig. 7. Codium setchellii. Mean mass ( \pm 1 SE) of algae transplanted to 3 wave-protected and 3 moderately wave-exposed areas at Boiler Bay after 7 wk in May and June 1989. Highly wave-exposed areas could not be used due to adverse tidal conditions. Number of transplants at each site is indicated above each bar 
period that the sea slugs were associated with the alga annually. Codium had 2 potential refuges from slug herbivory: (1) conditions of low slug densities, and (2) conditions of low feeding rates (Fig. 8). High wave action and sand movement may provide both types of refuges, thus enabling Codium to persist along the Oregon coast.

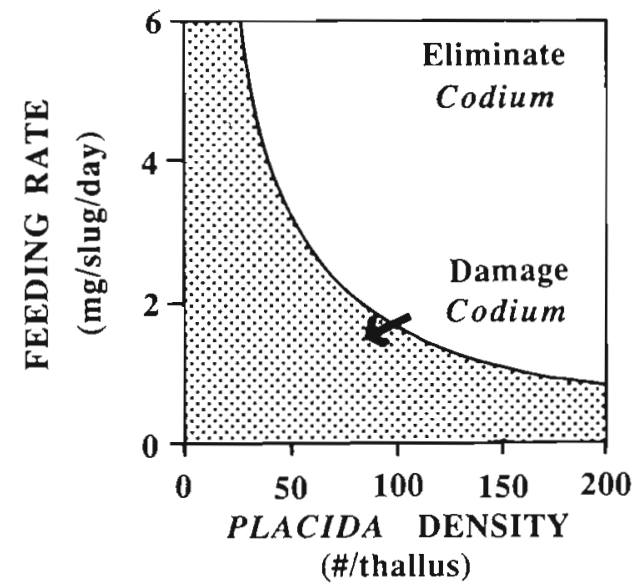

Fig. 8. Conditions of sea slug density and feeding rates under which $30 \mathrm{~g}$ Codium setchellii $(\sim 80 \%$ of thalli are $\leq$ this size) will be damaged versus eliminated by Placida dendritica herbivory during a single 6 mo season. Values based on laboratory-calculated sea slug feeding rates and observed field densities

\section{DISCUSSION}

\section{Herbivore attributes}

The role of herbivory in structuring plant populations is a function of the frequency and severity of herbivore attack and the consequences to the plants of grazing damage (Lubchenco \& Gaines 1981). Several herbivore features contributed to the effectiveness of slug herbivory. First, the probability of individual Codium thalli being located by Placida was high because of relatively high local slug densities, larval recruitment, and adult movement during the spring and summer (Trowbridge 1989, 1992). Hence, Codium did not have an effective low-density refuge from the sea slugs: all transplants were attacked. Second, Placida formed feeding groups on Codium, and group members facilitated the feeding of conspecifics (Trowbridge 1991b). Gregarious behavior, thus, enabled sea slugs to attack and damage Codium thalli. Third, the extreme diet specificity of Placida individuals (Trowbridge 1991a) may have concentrated slug feeding on Codium, even when alternate host species such as Bryopsis were available.

To evaluate the conditions under which mesoherbivory may be ecologically important, we need to consider the generality of the herbivore attributes mentioned above. Many mesoherbivores, particularly amphipods and isopods, exhibit high population densities (Gunnill 1982a, b. Norton \& Benson 1983, Salemaa 1987). Furthermore, although mesoherbivore movement has not been extensively examined, recent studies suggest considerable movement of crustaceans and gastropods among food plants (Gunnili 1982a, b, Johnson \& Mann 1986, Brawley \& Fei 1987, Trowbridge 1989, 1992). Gregarious feeding behavior and trophic facilitation among group members, however, appears uncommon in marine herbivores. Whether this pattern is an artifact of which marine herbivores have been studied (primarily larger, generalist taxa) or whether the pattern reflects some constraint of marine life is not known. Finally, diet specificity also appears relatively uncommon in marine herbivores though recent studies reveal considerable diet specificity in opisthobranch slugs (Paul \& Van Alstyne 1988, Hay et al. 1989, 1990a, b, Jensen 1989, Trowbridge 1991a) as well as in some limpets, amphipods, and crabs (Hines 1982, Steneck 1982, Hay et al. 1989, 1990a, b). Polyphagous herbivores may provide food plants with partial refuges, based on the relative abundance, composition, and physiognomy of neighboring species. For example, seaweeds may have associational refuges (Hay 1986, Pfister \& Hay 1988) where neighboring species deter approaching herbivores. Alternatively, relatively unpalatable species, such as Codium, may experience low herbivory if they associate with palatable neighbors. This latter type of refuge has received little attention.

The extent to which mesoherbivores damage seaweeds is a function not only of the quantity but also the quality of algal biomass removed. Herbivores that attack structurally or functionally strategic parts of plants may cause significantly more loss of biomass than the amount actually consumed. Examples of strategic parts include the base of Codium fragile branches (Clark 1975, author's pers. obs.), base of kelp stipes (Fralick et al. 1974, Dayton 1985), frilled margins of kelp laminae (Johnson \& Mann 1986), or lower parts of algal filaments (Clark 1975). Although most ascoglossan slugs appear to attack primarily terminal parts of thalli (Gascoigne \& Sartory 1974, Clark 1975, Jensen 1981, 1983, Jensen \& Clark 1983, Gosliner 1987, Paul \& Van Alstyne 1988), grazing by Placida fragmented Codium in situ and in transplant experiments, rendering the algae vulnerable to wave dislodgment. Other potential ways in which mesoherbivores (and larger herbivores) may affect seaweed populations include preferentially attacking stressed or reproductive thalli (Steinberg 1984, Gaines 1985, Gunnill 1985, Watson \& Norton 1985, Waugh \& Clark 1986), altering plant metabolism, and transmitting plant diseases (Clark \& DeFreese 1987). The relative importance of these different mechanisms has been largely ignored. 
A final attribute to be considered is the extent to which herbivore populations are restricted by predators. In some cases, predation may limit mesoherbivory (Young et al. 1976, Van Dolah 1978, Nelson 1979a, b, 1981, Zimmerman et al. 1979, Warwick et al. 1982). The importance of predation for many small herbivores, particularly ascoglossan opisthobranchs, is not well known. If predation was important in limiting Placida densities on Codium hosts, then my transplant experiments may overestimate the importance of Placida herbivory because the coarse mesh used to secure the alga to the substrate excluded many predators. Although a comparison of ascoglossan densities on transplants and on naturally established thalli at the same site would have been ideal, the scarcity of Codium setchellii hosts at the non-sandy site and the unpredictable sand inundations at sandy sites made such a comparison not feasible. Yet, the high densities of Placida on low intertidai Codium fragile at Boiler Bay (Trowbridge 1989, 1992) indicate that predation did not eliminate the oligophagous sea slugs.

\section{Algal attributes}

Several attributes of Codium contributed to effectiveness of herbivory by Placida. First, the alga had a high apparency in the low intertidal zone. It overgrew most other species (Quinn 1982, author's pers. obs.), including upright, branching algae and invertebrates. Thus, Codium was readily accessible to mobile, low intertidal herbivores searching for food. The alga also may have had a high chemical apparency because recruiting sea slugs located algal transplants within days. Second, although Codium had effective defenses against solitary slugs (Trowbridge 1991b) and probably small generalist mesoherbivores, the alga lacked an inducible response effective in deterring subsequent sea slug recruitment or feeding. Thus, attacked thalli were often reattacked and extensively damaged.

Third, Codium had a small-size rather than a large-size refuge from slug attack. For large-size refuges, once prey reach a certain threshold size, prey mortality to the consumer is relatively low. Spatial and temporal dynamics of prey recruitment and consumer feeding during the prey's vulnerable stage govern future prey distribution (Connell 1975). For long-lived prey species with small-size refuges, the period of vulnerability to consumers is longer, thus consumers have a greater chance of affecting prey distribution and abundance. For example, the long-lived perennial Codium was exposed to slug attack every spring and summer; intense herbivory in any given year may shape the algal distribution and abundance for subsequent years. Apparently low, episodic algal recruitment and slow thallus growth contributed to the alga's vulnerability to slug attack.

\section{Environmental conditions}

Connell (1975) suggested that sessile prey often have broader tolerance to harsh environmental conditions than do consumers. Codium had a broader tolerance to wave action and sand movement than did Placida: the alga inhabited wave-swept shores where sea slugs did not persist, and the alga tolerated the physical abrasion of sand scour as well as the adverse conditions of unpredictable sand burial. Physical disturbance such as high wave action and moving sand may reduce consumer movement and abundance (Menge 1982, D'Antonio 1986), particularly for small herbivores with low tenacity (Miller 1974, Denny et al. 1985). Disturbance may prevent larval settlement, enhance juvenile and adult dislodgment, or prompt herbivore emigration from food plants.

If harsh conditions, however, are spatially or temporally variable, environmentally mediated prey refuges may not be absolute: consumers with high larval recruitment or adult mobility may enter the refuges. Most marine invertebrate herbivores, including ascoglossan slugs (Clark 1975, Jensen \& Clark 1983, Hadfield \& Miller 1987, Strathmann 1987, references therein), have planktonic larvae as the major dispersal stage. Placida recruitment was continuous and often high during the spring and summer (Trowbridge 1992), enabling sea slugs to recruit to Codium in wave-swept or sand-disturbed areas during periods of low wave action or low sand inundation. Mesoherbivores often move actively among plants on a local scale (Gunnill 1982a, b, Johnson \& Mann 1986, Brawley \& Fei 1987, Trowbridge 1992). Consumers with either short generation times or high mobility, relative to the frequency of disturbance, may inhabit 'marginal' habitats along with the prey species. Long-lived consumers with low mobility and low recruitment (e.g. Pisaster and Nucella; Connell 1975) may be excluded from such habitats, thus enabling the prey to have a non-coexistence refuge.

In conclusion, sea slug mesoherbivory may restrict the between-site distribution of one low intertidal green alga along the Oregon coast. Slugs were more abundant, produced more grazing damage, and removed more algal biomass than co-occurring generalist molluscs and crustaceans. A variety of attributes of Placida and Codium contributed to the effectiveness of slug herbivory. Spatial and temporal variation in physical disturbance appeared to dictate the conditions in which Placida and Codium coexisted. To understand the conditions under which mesoherbivory structures marine communities, we need to focus our attention on both generalist and specialist consumers and the specific attributes that enhance their effectiveness. 
Acknowledgements. I thank J. Lubchenco and B. Menge for inspiration, advice, and support. J. Lubchenco, B. Menge, T Turner, L. Wolf, T. Farrell, M. Wilson, M. Hixon, M. Hay, K. Clark, and 2 anonymous reviewers made valuable comments on drafts of this manuscript. L. Weber kindly provided facilities and logistical support at the Hatfield Marine Science Center This research was supported by the Zoology Department and a Bayley Fellowship, Oregon State University; Reynolds Scholarship, Hatfield Marine Science Center; Mazamas Research Grant; Lerner-Gray Fund Grant; Sigma Xi Grant-inAid of Research; Hawaiian Malacological Society Scholarship Grant; and National Science Foundation grants OCE-8415609 and OCE-8811369 to B. Menge and OCE-8600523 to J. Lubchenco and D. Carlson.

\section{LITERATURE CITED}

Brawley, S. H., Adey, W. H. (1981a). Micrograzers may affect macroalgal density. Nature, Lond. 292: 177

Brawley, S. H., Adey, W. H. (1981b). The effect of micrograzers on algal community structure in a coral reef microcosm. Mar. Biol. 61: 167-177

Brawley, S. H., Fei, X. G. (1987). Studies of mesoherbivory in aquaria and in an unbarricaded mariculture farm on the Chinese coast. J. Phycol. 23: 614-623

Brostoff, W. N. (1988). Seaweed community structure and productivity: the role of mesograzers. Proc. 6th int. coral Reef Symp. 2: 1-6

Clark, K. B. (1975). Nudibranch life cycles in the Northwest Atlantic and their relationship to the ecology of fouling communities. Helgoländer wiss. Meeres. 27: 28-69

Clark, K. B., Busacca, M. (1978). Feeding specificity and chloroplast retention in four tropical ascoglossa, with a discussion of the extent of chloroplast symbiosis and the evolution of the order. J. mallusc. Stud 44:272-282

Clark, K. B., DeFreese, D. (1987). Population ecology of Caribbean Ascoglossa (Mollusca: Opisthobranchia): a study of specialized algal herbivores. Am malac. Bull. 5: 259-280

Clark, K. B., Jensen, K. R., Stirts, H. M. (1990). Survey for functional kleptoplasty among west Atlantic ascoglossa (=sacoglossa) (Mollusca: Opisthobranchia). Veliger 33: 339-345

Coen, L. D. (1988a). Herbivory by Caribbean majid crabs: feeding ecology and plant susceptibility. J. exp. mar. Biol. Ecol. 122: $257-276$

Coen, L. D. (1988b). Herbivory by crabs and the control of algal epibionts on Caribbean host corals. Oecologia 75 ; 198-203

Connell, J. H. (1975). Some mechanisms producing structure in natural communities: a model and evidence from field experiments. In: Cody, M. L., Diamond, J. M. (eds.) Ecology and evolution of communities. Harvard University Press, Cambridge, Massachusetts, p. 460-490

D'Antonio, C. (1985). Epiphytes on the rocky intertidal red alga Rhodomela larix (Turner) C. Agardh: negative effects on the host and food for herbivores? J. exp. mar. Biol. Ecol. 86: $197-218$

D'Antonio. C. M. (1986). Role of sand in the domination of hard substrata by the intertidal alga Rhodomela larix. Mar. Ecol. Prog. Ser 27: 263-275

Dayton, P. K. (1985). Ecology of kelp communities. A. Rev Ecol. Syst. 16: 215-245

Denny, M. W., Daniel, T. L., Koehl, M. A. R. (1985). Mechanical limits to size in wave-swept organisms. Ecol. Monogr. 55: $69-102$
Duffy, J. E. (1990). Amphipods on seaweeds: partners or pests? Oecologia 83: $267-276$

Duffy, J. E., Hay, M. E. (1991). Amphipods are not all created equal: a reply to Bell. Ecology 72: 354-358

Fralick, R. A., Turgeon, K. W., Mathieson, A. C. (1974). Destruction of kelp populations by Lacuna vincta (Montagu). Nautilus 88: 112-114

Gaines, S. D. (1985). Herbivory and between-habitat diversity: the differential effectiveness of defenses in a marine plant. Ecology 66: 473-485

Gascoigne, T., Sartory, P. K. (1974). The teeth of three bivalved gastropods and three other species of the order Sacoglossa. Proc. malac. Soc. Lond. 41. 109-126

Gosliner, T (1987). Nudibranchs of Southem Africa: a guide to opisthobranch molluscs of Southern Africa. Sea Challengers, Monterey, California

Gunnill, F. C. (1982a). Macroalgae as habitat patch islands for Scutellidium lamellipes (Copepoda: Harpacticoida) and Ampithoe tea (Amphipoda: Gammaridae). Mar. Biol. 69: 103-116

Gunnill, F. C. (1982b). Effects of plant size and distribution on the numbers of invertebrate species and individuals inhabiting the brown alga Pelvetia fastigiata. Mar. Biol. 69: $263-280$

Gunnill, F. C. (1985). Growth, morphology and microherbivore faunas of Pelvetia fastigiata (Phaeophyta, Fucaceae) at La Jolla, California, U. S. A. Botanica mar. 28: 187-199

Hadfield, M. G., Miller, S. E. (1987). On developmental patterns of opisthobranchs. Am. Malac. Bull. 5: 197-214

Hawkins, S. J., Hartnoll, R. G. (1983). Grazing of intertidal algae by marine invertebrates. Oceanogr. mar. Biol. A. Rev. 21: $195-282$

Hay, M. E. (1986). Associational plant defenses and the maintenance of species diversity: turning competitors into accomplices. Am. Nat. 128: 617-641

Hay, M. E., Duffy, J. E., Pfister, C. A., Fenical, W. (1987). Chemical defense against different marine herbivores: are amphipods insect equivalents? Ecology 68: 1567-1580

Hay, M. E., Renaud, P. E., Fenical, W. (1988a). Large mobile versus small sedentary herbivores and their resistance to seaweed chemical defenses. Oecologia 75: 246-252

Hay, M. E., Duffy, J. E., Fenical, W., Gustafson, K. (1988b). Chemical defense in the seaweed Dictyopteris delicatula: differential effects against reef fishes and amphipods. Mar. Ecol. Prog. Ser. 48: 185-192

Hay, M. E., Pawlik, J. R., Duffy, J. E., Fenical W. (1989). Seaweed-herbivore-predator interactions: host-plant specialization reduces predation on small herbivores. Oecologia 81: 418-427

Hay, M. E., Duffy, J. E., Fenical, W. (1990a). Host-plant specialization decreases predation on a marine amphipod: an herbivore in plant's clothing. Ecology 71: 733-743

Hay, M. E., Duffy, J. E., Paul, V. J., Renaud, P. E. Fenical, W. (1990b). Specialist herbivores reduce their susceptibility to predation by feeding on the chemically defended seaweed Avrainvillea longicaulis. Limnol. Oceanogr. 35: 1734-1743

Hinde, R., Smith, D. C. (1974). Chloroplast symbiosis and the extent to which it occurs in Sacoglossa (Gastropoda: Mollusca). Biol. J. Linn. Soc. 6: 349-356

Hines, A. H. (1982). Coexistence in a kelp forest: size, population dynamics, and resource partitioning in a guild of spider crabs (Brachyura, Majidae). Ecol. Monogr. 52:179-198

Jensen, K. (1975). The importance of Limapontia capitata (Mueller) (Opisthobranchia, Sacoglossa) as a primary consumer in the Cladophora-belt. Fifth Eur. Symp. Mar. Biol. 2: $339-350$ 
Jensen, K. R. (1981). Observations on feeding methods in some Florida ascoglossans. J. mollusc. Stud. 47 190-199

Jensen, K. R. (1983). Factors affecting feeding selectivity in herbivorous Ascoglossa (Mollusca: Opisthobranchia). J exp. mar. Biol. Ecol. 66: 135-148

Jensen, K. R. (1989). Learning as a factor in diet selection by Elysia viridis (Montagu) (Opisthobranchia). J. mollusc Stud. 55: 79-88

Jensen, K., Clark, K. B. (1983). Annotated checklist of Florida ascoglossan opisthobranchia. Nautilus 97: 1-13

Johnson, C. R., Mann, K. H. (1986). The importance of plant defence abilities to the structure of subtidal seaweed communities: the kelp Laminaria longicruris de la Pylaie survives grazing by the snail Lacuna vincta (Montagu) at high population densities. J. exp. mar Biol. Ecol. 97: 231-267

Lubchenco, J., Gaines, S. D. (1981). A unified approach to marine plant-herbivore interactions. I. Populations and communities. A. Rev. Ecol. Syst. 12: 405-437

McLean, N. (1976). Phagocytosis of chloroplasts in Placida dendritica (Gastropoda: Sacoglossa). J. exp. Zool. 197 $321-330$

Menge, B. A. (1982). Effects of feeding on the environment: Asiervided. in: Jangoux, ivi., Lawrence, J. Mi. (eds.) Echinoderm Nutrition. Balkema, Rotterdam, p. 521-551

Miller, S. L. (1974). Adaptive design of locomotion and foot form in prosobranch gastropods. J. exp. mar. Biol. Ecol. 14: 99-156

Nelson, W. G. (1979a). Experimental studies of selective predation on amphipods: consequences for amphipod distribution and abundance. J. exp. mar. Biol. Ecol. 38: 225-245

Nelson, W. G. (1979b). An analysis of structural pattern in an eelgrass (Zostera marina L.) amphipod community. J. exp. mar. Biol. Ecol. 39: 231-264

Nelson, W. G. (1981). Experimental studies of decapod and fish predation on seagrass macrobenthos. Mar Ecol. Prog. Ser. 5: 141-149

Nicotri, M. E. (1977). The impact of crustacean herbivores on cultured seaweed populations. Aquaculture 12: 127-136

Nicotri, M. E. (1980). Factors involved in herbivore food preference. J. exp. mar. Biol. Ecol. 42: 13-26

Norton, T A., Benson, M. R. (1983). Ecological interactions between the brown seaweed Sargassum muticum and its associated fauna. Mar Biol. 75: 169-177

Paul, V. J., Van Alstyne, K. L. (1988). Use of ingested algal diterpenoids by Elysia halimedae Macnae (Opisthobranchia: Asocglossa) as antipredator defenses. J. exp. mar. Biol. Ecol. 119: 15-29

Pfister, C. A., Hay, M. E. (1988). Associational plant refuges: convergent patterns in marine and terrestrial communities result from differing mechanisms. Oecologia 77: 118-129

Quinn, J. F. (1982). Competitive hierarchies in marine benthic communities. Oecologia 54: 129-135

Rabinowitz, D. (1981). Seven forms of rarity. In: Synge, $H$. (ed.) The biological aspects of rare plant conservation Wiley, Chichester, p. 205-217

Salemaa, H. (1987). Herbivory and microhabitat preferences of Idotea spp. (Isopoda) in the northern Baltic Sea. Ophelia 27: $1-15$

Santisi, S. (1985). Osservazioni ultrastrutturali su plastidi di

This article was presented by M. Hay, Morehead City, North Carolina, USA
Bryopsis duplex <<simbionti $>>$ nei cerata di Hermaea dendritica. Oebalia 11.863-866

Schmekel, L., Portmann, A. (1982). Opisthobranchia des Mittelmeeres: Nudibranchia und Saccoglossa. SpringerVerlag, Berlin

Silva, P. C. (1951). The genus Codium in California with observations on the structure of the walls of the utricles. Univ. Calif. Publs. Bot. 25: 79-114

Steinberg, P. D. (1984). Algal chemical defense against herbivores: allocation of phenolic compounds in the kelp Alaria marginata. Science 223: 405-407

Steneck, R. S. (1982). A limpet-coralline alga association: adaptations and defenses between a selective herbivore and its prey. Ecology 63: 507-522

Strathmann, M. F. (1987). Reproduction and development of marine invertebrates of the northern Pacific coast. University of Washington Press, Seattle, Washington

Tegner, M. J., Dayton, P. K. (1987). El Niño effects on southern California kelp forest communities. Adv. ecol. Res. 17: 243-279

Trench, R. K. (1975). Of 'leaves that crawl': functional chloroplasts in animal cells. In: Jennings, D. H., Lee, D. L. (eds.) Symbiosis. Cambridge University Press, Cambridge, p. $229-265$

Trowbridge, C. D. (1989). Marine herbivore-plant interactions: the feeding ecology of the sea slug Placida dendritica. Ph.D. thesis, Oregon State University, Corvallis

Trowbridge, C. D. (1991a). Diet specialization limits herbivorous sea slug's capacity to switch among food species. Ecology 72: 1880-1888

Trowbridge, C. D. (1991b). Group membership facilitates feeding of the herbivorous sea slug Placida dendritica. Ecology 72: 2193-2203

Trowbridge, C. D. (1992). Phenology and demography of a marine specialist herbivore: Placida dendritica (Gastropoda: Opisthobranchia) on the central coast of Oregon. Mar. Biol. (in press)

Van Dolah, R. F. (1978). Factors regulating the distribution and population dynamics of the amphipod Gammarus palustris in an intertidal salt marsh community. Ecol Monogr. 48: 191-217

Warwick, R. M., Davey, J. T., Gee, J. M., George, C. L. (1982) Faunistic control of Enteromorpha blooms: a field experiment. J. exp. mar. Biol. Ecol. 56: 23-31

Watson, D. C., Norton, T A. (1985). Dietary preferences of the common periwinkle, Littorina littorea (L.). J. exp. mar. Biol Ecol. 88: 193-211

Waugh, G. R., Clark, K. B. (1986). Seasonal and geographic variation in chlorophyll level of Elysia tuca (Ascoglossa Opisthobranchia). Mar. Biol. 92: 483-487

Wilkinson, L. (1988). SYSTAT: The system for statistics. SYSTAT, Inc., Evanston, Illinois

Young, D. K., Buzas, M. A., Young, M. W (1976). Species densities of macrobenthos associated with seagrass: a field experimental study of predation. J. mar Res. 34: 577-592

Zar, J. H. (1984). Biostatistical analysis, 2nd ed. Prentice-Hall, Inc., Englewood Cliffs, New Jersey

Zimmerman, R, Gibson, R., Harrington, J. (1979). Herbivory and detritivory among gammaridean amphipods from a Florida seagrass community. Mar Biol. 54: 41-47

Manuscript first received: March 30, 1991

Revised version accepted: April 15, 1992 